ANL/RER/75-2

\title{
OBSERVATIONS OF ATMOSPHERIC STRUCTURE USING AN ACOUSTIC SOUNDER
}

\author{
by
}

N. A. Shaw*

November 1974

\section{Radiological and Environmental Research Division Atmospheric Physics Section Argonne National Laboratory 9700 South Cass Avenue Argonne, Illinois 60439}

This report was prepared as an account of work
sponsored by the United States Government. Neither
the United States nor the United States Energy
Rescarch and Development Administration, nor any of
their employes, not any of their contractors,
subcontractors, or their employees, makes any
warniy, express or implied, or assumes any legal
linbility or responsibility for the accuracy, completencss
or usefulness of any information, apparatus, product or
process disclosed, or ripresents that its use would not
infringe privately owned rights.




\section{ABSTRACT}

An acoustic sounder has been used to monitcr the vertical temperature structure of the lowest $1.5 \mathrm{krn}$ of the atmosphere over the meteorological field site at Prgonne National Laboratory since February 1972. Additional records were obtained near St. Louis, Mo., during the rionth of August as a contribution to the Metropolitan Meteorological Experiment. This paper summarizes the results; of the first year of operation.

In this preliminary report, sounder records obtained during cloudless days on which no major synoptic events occurred are separated into three characteristic phases. During the first phase, the records show the rise of the morning inversion associated with increasing solar heating of the surface after dawn. The second phase is the period of strong convective activity that usually exists between about 1100 and 1600 local time in summer and which typically destroys the inversion. The third phase includes the gradual regeneration of the low level inversion through radiation cooling of the lowest levels, followed by a period of persistence throughout the night untll the first phase begins again after sunrise.

Acoustic sounding techniques show the presence and height of inversion layers in real time, in some conditions with an accuracy superior to that obtained by more conventional direct measurement. This is particularly true during the first phase of the diumal cycle, when sounder records show the rise and eventual brakup of the nocturnal inversion with great clarity and thus provide highly accurate estimates of the rapidly changing mixing height through the morning hours. In addition, other thermally layered structures associated with rapidly changing siynoptic events are clearly depicted on the continuous sounder charts.

Analysis of records obtained from a single acoustic sounder operating in the vertically-pointing, monostatic mode is, of course, subject to the usual ambiguity regarding the relative importance of advective effects and local changes 
with time. To provide a spatlal sampling facllity, a moblle acoustlc sounding system was constructed during 1972 . Detalls of the mobile antenna acoustic baffle or cuff are given in the Appendix.

\section{Introduction}

Since the vertical density structure of the lower atmosphere is a major factor influencing the dispersion of atmospheric pollutants, the ability to monitor the presence and height of temperature inversions is of considerable value of both forecasting and research. This information can be provided by acoustlc sounding techniques,

(1) which are able to detect the acoustic energy scattered back, or echoed, by the thermal turbulence usually found in or near atmospheric temperature inversions. An acoustic sourder of the type developed by Boume and Shaw ${ }^{(2-4)}$ was installed at Angonne National Laboratory in early February, 1972, and has since been operating in the vertically-pointing, monostatic mode on a more or less continuous basis. During the ensuing year, the sounder has recorded the altitude and approximate intensities of temperature Irregularities in the lowest $1.5 \mathrm{~km}$ of the atmosphere. Records obtained show the development and breakup of nocturnal inversions, the evolution of the daytime convectively-mixed layer, frontal passages, subsidence inversions, and the occasional passage of lake-breeze fronts originating over Lake Michigan.

Although Argonne was the observing site for most of the year, the sounder was also located near St. Louls for a six-week period in midsummer as part of the 1972 field program of the Metropolitan Meteorological Experiment (Metromex).

This report summarizes the results of experiments conducted during 1972 and illustrates them with a selection of analyzed data. Particular attention is paid to the diumal cycle of the atmospheric mixed layer, and to the ability of the acoustic sounding technique to monitor the mixing height continuously. 


\section{Operation and Deployment}

The acoustic sounder used in these studies radiates into the lower atmosphere an intense pulse of sound, approximately $60 \mathrm{~W}$ at a frequency near $1 \mathrm{kHz}$. A small fraction of this transmitted energy is backscattered by temperature Irregularities in the atmosphere (and reflected from nearby buildings and towers) and eventually returned to the paraboloidal dish of the acoustic antenna. A facsimile recorder displays the combined signal strength of the echoes and background noise recelved as a function of time delay which can be interpreted as height. The electronic circuitry of the acoustic sounder has been described by Shaw. ${ }^{(4)}$ The $1.5-\mathrm{m}$ diameter antenna, used with the ANL equipment confines most of the radlated energy in a veitically-pointing beam measuring $14 \mathrm{deg}$ between half-power points, but some of the sound is radiated in side lobes at very low elevation angles. These minor side lobes are partly or wholly responsible for a number of problems that hinder operation of a vertically-pointing acoustic sounder in nolsy or builtup areas:

1. Undeisired echoes from neighboring obstacles add to genuine atmospheric returns to produce an ambiguous record. Such extraneous signals (commonly known as "clutter") are usually fixed in range and. therefore, can be distingulshed from genulne atmospheric echoes, which typically change in helght and intensity with time.

2. Major sources of amblent nolse located at or near ground level cause undesired signals to be detected either by the antenna or directly by the transducer mounted at its focus. In addition to obvious noise sources such as highway traffic and trains, wind noise can also be significant. Aircraft passing overhead do not ordinarily present a serious problem because of the comparatively short time they remain in a given area.

3. Although the intensity of sound radiated through the minor side lobes is more than $30 \mathrm{db}$ less than that of the peak value of the main lobe, the tone emitted by an unshiglded antenna is still clearly audible at horizontal distances up to several hundred meters. In a quiet residentlal area this nolse 
may be annoylng and undeslrable.

A simple but most effective technique of alleviating these problems Is to place the anterna in a deep hole in the ground, preferably excavated in a manner so that no two sides are parallel, thereby reducing the poss1billity of multiple reflections or "ringing." Fine mosquito netting placed across the hole helps dissipate wind eddies and thus reduces turbulent wind nolse in the vicinity of the transducer.

During the first half of 1972 the Argonne acoustic sounder antenna was placed in a 3.7-m deep hole near the meteorological bullding. A simllar arrangement was used at a field site near St. Louls during the 1972 Metromex program. At these sites the antenna-in-hole configuration essentially eliminated clutter, and the side-lobe nolse at ground level nearby was not consldered annoying.

There are two problems inherent in the use of the antenna-in-hole system, namely the difficulity in keeping the hole free of rain and ground water and the lack of mobllity afforded by such a permanent installation. To offset both of these, an antenna was mounted on the flat bed of a standard traller and a $2.4-\mathrm{m}$ high, tapered cuff made of plywood, lead, and foam plastic sheet was constructed around the antenna dish (see Appendix). The performance of this unit with respect to the three points listed above was evaluated in both rural and urban environments, and a comparison with the effectiveness of a permanent hole installation was made. Although it was found that this so-called "portable hole" did not reject nolse as efficiently as did the permanent hole, the moblle unit did show an improvement of more than $15 \mathrm{db}$ relative to antenna performance in an unprotected, free-field environment.

Acoustic sounder records obtaized with the mobile cuff system for normal routine operations. When used with a battery-operated sounder, the moblle equipment could be operated at any convenlent location, although It was found that amblent noise levels in downtown city areas were detrimental to the quality of the records obtained. Detalls of the cuff design 
and its acoustic performance are presented in the Appendix.

\section{Observations of Typical Diumal Cycles}

On a clear night the earth's surface cools by emitting long-wave radiation, and a surface-based, "nocturnal" inversion in the vertical distribution of temperature often develops in the lower atmosphere. For purposes of the discussion to follow, three phases of diurnal development may be Identlfied. Shortly after sunrise Phase I begins as the air near the ground Is warmed and convective mixing starts to erode the inverston from the surface upwards; the upward growth of a well-mixed, adlabatic region causes the inversion layer to ascend, weaken, and eventually disappear. With the generation of full-scale convective plumes in Phase II, a comparatively deep, well-mixed surface layer is established. These conditions usually prevail untll near sunset, when the decreasing solar radiation recelved at the ground can no longer supply the thermal energy required to maintain the convective plumes; with the setting of the sun, the nocturnal inversion begins to redevelop for Phase III.

Since the breakup of the inversion in Phase I is of particular interest to air pollution meteorologists, this period has been investigated with the assistance of multiple radiosonde ascents, surface temperature observations and LIDAR soundings. " In what follows, variations on a conventional model of the morning inversion breakup are considered, and the performance of these techniques in predicting the mixing helght is compared with acoustic sounder observations.

\subsection{Phase I. The Morning Breakup of the Nocturnal Inversion}

Consider a surface-based inversion of the type which often exists in the lower atmosphere during predawn hours. Flgure $1(A)$ represents this situation with the simplified temperature profile PQR. Soon after sunrise,

*A comparison between LIDAR (laser radar) and acoustic sounding techniques was made during the 1972 METROMEX program by Argonne and the Stanford zesearch Instltute ${ }^{(6)}$. 

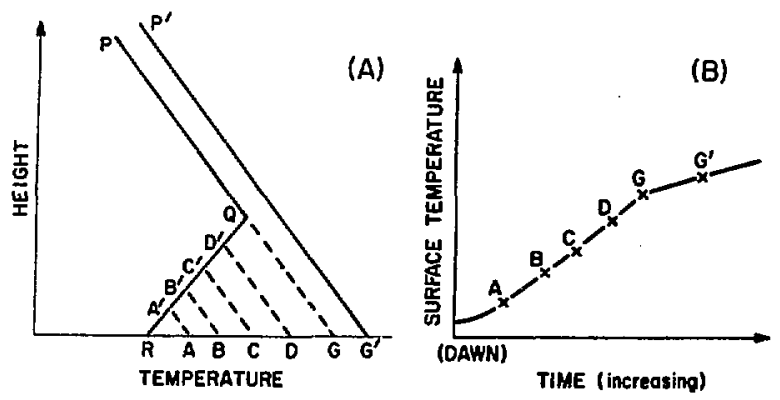

Fig. 1.--(A) Schematic vertical profiles of temperature from sunrise to midday; (B) a typical surface temperature record from sumrise to midday. [ ANL Neg. No. 149-5502 Rev. 1]

the air near the surface is warmed and an adiabatic or superadiabatic lapse rate develops through the lowest few tens of meters ، glving rise to a new profile which may be represented by $P Q A ' A$. Assuming that the upper levels of the profile remain essentlally unchanged and that the effects of solar heating on the atmosphere are largely confined to the convectively-mixed layer near the surface, the temperature proflle can be expected to develop through the stages represented by $P Q B{ }^{\prime} B, P Q C^{\prime} C$, etc. until an adiabatic lapse rate is established throughout the lower atmosphere (PQG). During the process, each of the points, $A^{\prime}, B^{\prime}, C^{\prime}$, etc. In the figure represents successive bases of the rising inversion, which gradually weakens with time and finally disappears at $Q$.

Corresponding to this model of an eroding temperature inversion, the surface temperature record behaves as illustrated in Figure 1 (B). The decrease in the rate of surface temperature change at $\mathrm{G}$ occurs after the inversion has been destroyed. That is, when the thermal plumes are able o penetrate to greater altitudes, the avallable solar energy input is distriuted through a larger volume; consequently the rate of temperature increase $t$ the surface is decreased, and the temperature profile evolves as PG-P'G'.

If we assume that an acoustic sounder detects echoes from the base $f$ an inversion (e.g., see Refs. 1, 3, and 4), we would expect a typical orning record should show a steadily rising echo structure that weakens ith altitude and finally disappears. Figure 2 is an example of this type of sunder recond which is almost always obtained on a morning after a clear or artly cloudy night with light to moderate surface winds. The two examples 


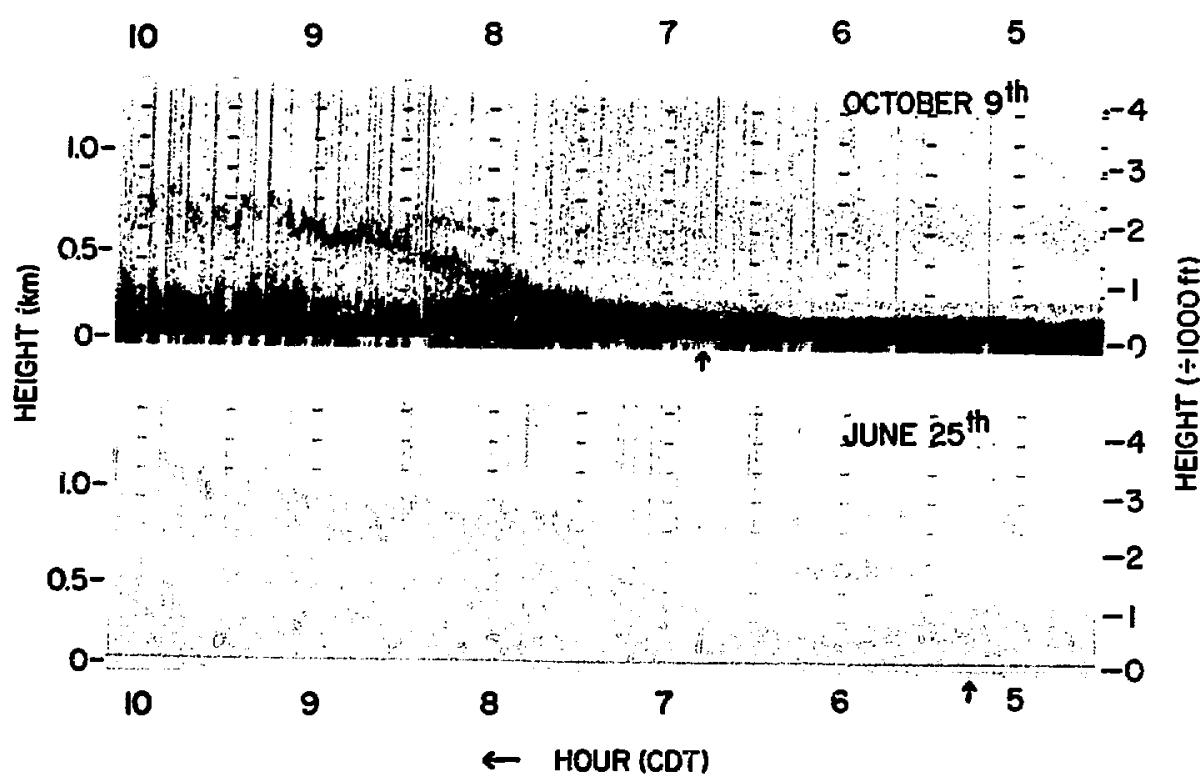

FIG. 2. --Examples of nocturnal inversion breakup recorded by an acoustic sounder. Sunrise is indicated by the arrows on the lower scales. [ANL. Neg. No. 149-5475 Rev. 1]

In the diagram show that before dawn, strong acoustic returns were obtained from very short ranges (approximately $200 \mathrm{~m}$ ); after sunrise the eche steadily ascended while decreasing in intensity until it finally disappeared. The two reconds presented in Figure 2 are chosen to lllustrate that the breakup of the nocturnal inversion commences scon after sunrise and that the time scale for an analysis of the developing mixing layer should be referred to the time of this critical event, rather than to some more arbitrary time reference. Strong echoes from the lower levels are often apparent during and after the inversion breakup, but further discussion of the nature of these returns will be deferred until consideration of Phase II. Although the two sounder records shown are sypical of morning observations obtained in the conditions described, the rate of rise of the inversion, the maximum inversion height attained, and the celative intensity of the echoes recorded can vary significantly according to he prevalling conditions. 
ing temperature profiles obtained from early morning radiosonde ascents and ə inversion breakup model described above, air pollution meteorologists ike dally estimates of the "morning mixing height." A technique frequently ed involves the addition of a small increment (typlcally 3 to $5 \mathrm{C}$ ) to the nimum surface temperature recorded during the early morning, and determines probable depth for the mixed layer by extending a dry-adiabatic lapse rate spe from this point on a thermodynamic diagram to an intersection with a plot the observed temperatire profile derived from the radiosone data. In the sernoon the maximum surface temperature observed is normally used without justment to obtain an "afternoon mixing height" in a similar fashion. It is sar that the magnitude of the temperature increment best suited to any partilar situation musi vary with a number of factors including the heat energy allable at the earth's surface (from solar radiation), the rate of mixing preiling in the lower atmosphere, and local topographic effects.. To a large :ent, these matters are taken into account (at least subjectively) by an Jerienced forecaster, who typically modifies the magnitude of the temperature rement to be added to suit his judgment of the characteristics of a particular lation.

Mixing heights indicated by the acoustic sounder located at the Argonne $\geqslant$ were compared with predictions of the "morning-mixing-height" model ied on surface temperature measurements and radiosonde observatiors orded at Chicago Midway Airport, located about $16 \mathrm{~km}$ to the northeast. hese comparisons the effect of the magnitude of the temperature increment $d$ in the model was examined by employing nine different values (multiples $.5 \mathrm{C})$ between 0.0 and $4.0 \mathrm{C}$. Each of these was added to each hourly le of the surface temperature recorded after sunrise to test the relative ats of the initial temperature on which the model was based. Extrapolaalong the dry-adlabatic slope of a thermodynamic diagram from each of e adjusted surface temperatures to the intercept of the observed temperaprofile then gave, for the time of sunrise and for each hour thereafter, a Jf nine different estimated mixing helghts. By connecting the successive 
hourly height estimates determined by each value of the temperature increment on a time-height plot, a family of curves showing various predicted trends of the depth of the developing mixed layer is generated for each occasion studied. Figures 3 and 4 present four analyses using this techntque, together with the corresponding temperature profiles measured by the morning radiosonde ascents. The examples are chosen to demonstrate the observed variability in the rate of rise of the mixing helght. Solid lines show the various predicted trends of inversion levels, or estimated mixing heights, corresponding to the various increments added to the hourly surface temperature. Curves labeled " 1 " in Figures 3 and 4 correspond to $0.0 \mathrm{C}$ added, and so on up to curves labeled "9," which correspond to $4.0 \mathrm{C}$ added. The broken lines drawn in the figures show the changing, measured heights of strong acoustic returns detected by the acoustic sounder.

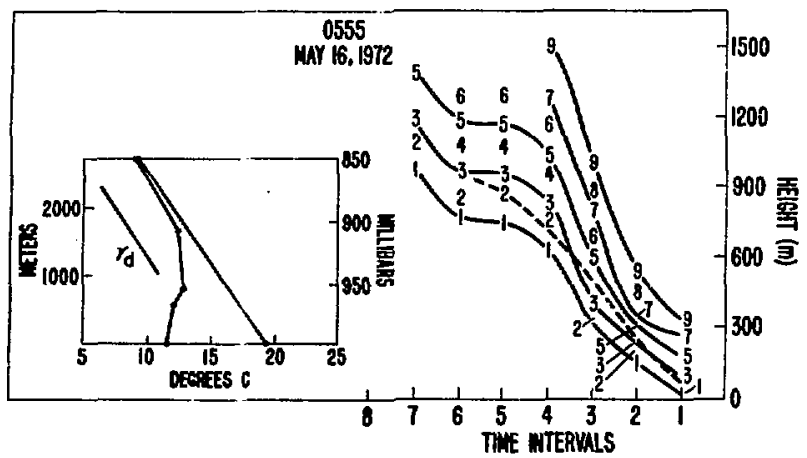

FIG. 3.--Examples of the comparison between morning inversion levels observed by an acoustic sounder and the mixing helghts predicted by the "estimated-mixing-height" model. Time intervals are hours from the indicated time of radiosonde launch. Farly

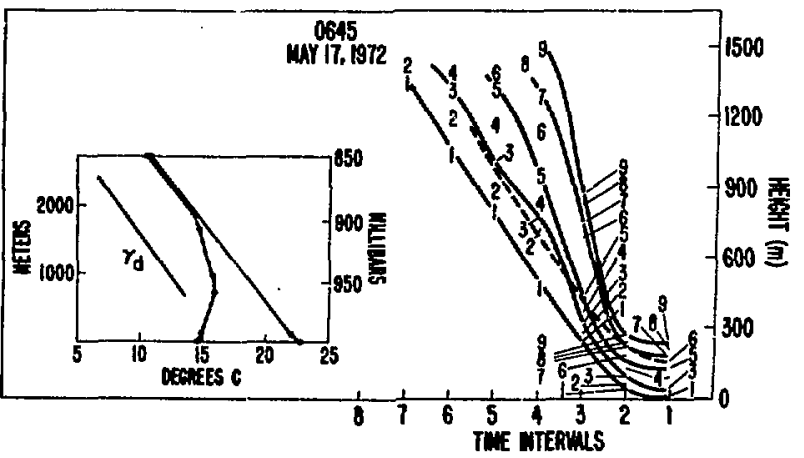
morning and noon temperature structures from radiosonde ascents are shown, and the dry-adiabatic lapse rate, $\boldsymbol{\gamma}_{d}$ ' is shown. [ANL Neg. No. 149-5501 Rev. 2] 

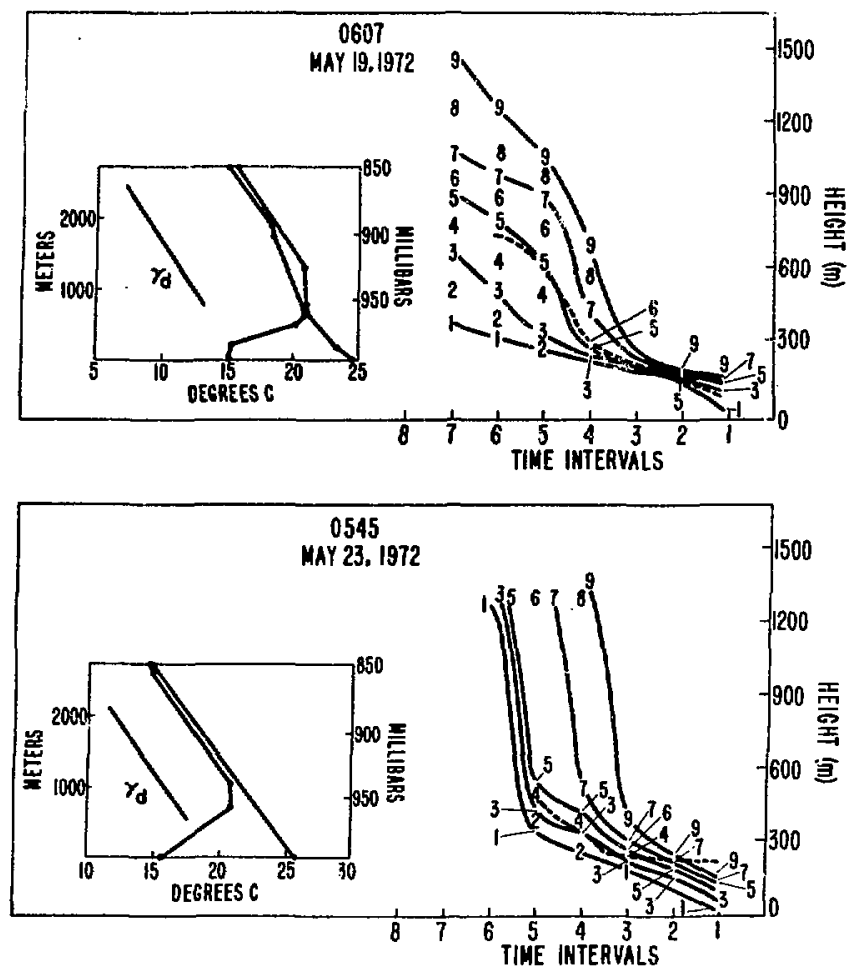

FIG. 4. --Further examples as in Figure 3. [ANL Neg. No. 149-5503 Rev. 2]

Both examples in Figure 3 show that the inversion levels detected by the acoustic sounder ascended unfformly and rapidly during the four-hour period following radiosonde launch, with the calculated mixing helghts following a simllar development. The bottom example of Figure 4 shows a slower rate of deepening of the mixed layer early in the morning, which continued until the inversion was completely eroded and, in effect, the mixing height suddenly increased. The top example in Figure 4 shows a more complicated development; here the estimated mixing height trend for the $2 \mathrm{C}$ increment (curve \#5) closely follows the acoustic sounder observations.

The difference between the estimated mixing height and the acoustic sounder's observations of the inversion base altitude was calculated for 12 different days, each day being examined in detall in the manner illustrated 
TABLE 1. Average helght differences (In meters) between inversion bases acoustic sounder and estlmated mixing helghts obtained using the model discussed in the text with varlous increments added to the surface temperature.

\begin{tabular}{|c|c|c|c|c|c|c|}
\hline \multirow[b]{2}{*}{$\Delta \mathrm{T},{ }^{\circ} \mathrm{C}$} & \multirow[b]{2}{*}{ Curve } & \multicolumn{4}{|c|}{ Time after radlosonde release, hr } & \multirow[b]{2}{*}{4} \\
\hline & & 0 & 1 & 2 & 3 & \\
\hline 0.0 & 1 & 137 & 88 & 90 & 112 & 151 \\
\hline 0.5 & 2 & 106 & 61 & 7 & 36 & 66 \\
\hline 1.0 & 3 & 79 & 34 & -24 & -13 & -17 \\
\hline 1.5 & 4 & 53 & 9 & -66 & -93 & -140 \\
\hline 2.0 & 5 & 33 & -72 & -111 & -205 & -435 \\
\hline 2.5 & 6 & 12 & -99 & -187 & -292 & -771 \\
\hline 3.0 & 7 & -9 & -126 & -238 & -396 & -991 \\
\hline 3.5 & 8 & -31 & -163 & -357 & -672 & -993 \\
\hline 4.0 & 9 & -53 & -203 & -429 & -865 & -1032 \\
\hline
\end{tabular}

in the diagrams of Figures 3 and 4. Table 1 summarizes the average difference between the predicted and observed mixing helghts as a function of both elapsed time after radiosonde launch and the magnitude of the increment added to the hourly surface temperatures. On the average, the actual mixing height at radiosonde launch time was best estimated when about $3 \mathrm{C}$ was added to the surface temperature, but for two to four hours later a $1 \mathrm{C}$ increment added to the current temperature appeared best. Whlle this average agreement is fairly encouraging, an analysis of variance shows that the table of average differences is not a reliable guide to individual cases.

A consistent discrepancy between the otherwise generally simllar observations and predictions lllustrated in Figures 3 and 4 arises from the fact that, in the early morning hours, the sounder cannot detect the bases of inversions very close to the ground. The minimum range at which echoes can be recorded is of course limited by the duration of the Initial transmitted pulse; with the 0.25 -s pulses usually used, inversion bases below $70 \mathrm{~m}$ were effectively obscured. When near-surface-based inversions were present, the sounder usually did detect some short-range atmospheric echoes but was 
unable to record their lower extremities. For these comparisons, the helghts of inversion bases recorded near dawn were taken to be best represented by the upper helghts of the apparent ground-based returns recorded, less one pulse length. Since the lowest inversion could have been falrly thick or have other inversions within $70 \mathrm{~m}$ above $\mathrm{it}$, the altitudes of inversion bases may have been overestimated in these early morning observations. As the inversion subsequently ascended, the lower edge of the echo layer soon became apparent in the record and from then on could be taken as a direct measurement of the Inversion base height.

Careful inspection of the results presented in Table 1 suggests that the simple "morning-mixing-height" model may be inadequate. It is possible that mechanisms of atmospheric heating other than simple convective mixing of heat received at the surface through insolation may be significant. Further, a superadiabatic region usually exists near the surface when the insolation is strong, whereas the simple model invariably assumes that a dry-adiabatic lapse rate exists between the surface and the inversion base. Finally, the present comparison between acoustic sounder and radiosonde results does not consider spatial differences between the two observing sites, in this case $16 \mathrm{~km}$ apart.

To remove some of these uncertainties, an observation program was conducted near St. Louis in which radiosondes were launched from the acoustic sounder site itself at regular intervals between sunrise and early afternoon. Some of these results are presented in Figures 5 and 6 in the form of temperature proflles and corresponding acoustic sounder records. To Identify the times of radiosonde ascents, a number has been assigned to each temperature proflle and printed on the time axis of the appropriate sounder record at the time of balloon release. To further assist the interpretation, the dry-adiabatic lapse $\left(\gamma_{d}\right)$ is indicated by a straight line on each profile chart.

Of the four examples displayed, only that of August 24 does not show the rising layer structure characteristic of the morning inversion breakup. Instead this example shows strong multilayered acoustic returns which descended slightly over a period of several hours and finally disappeared 


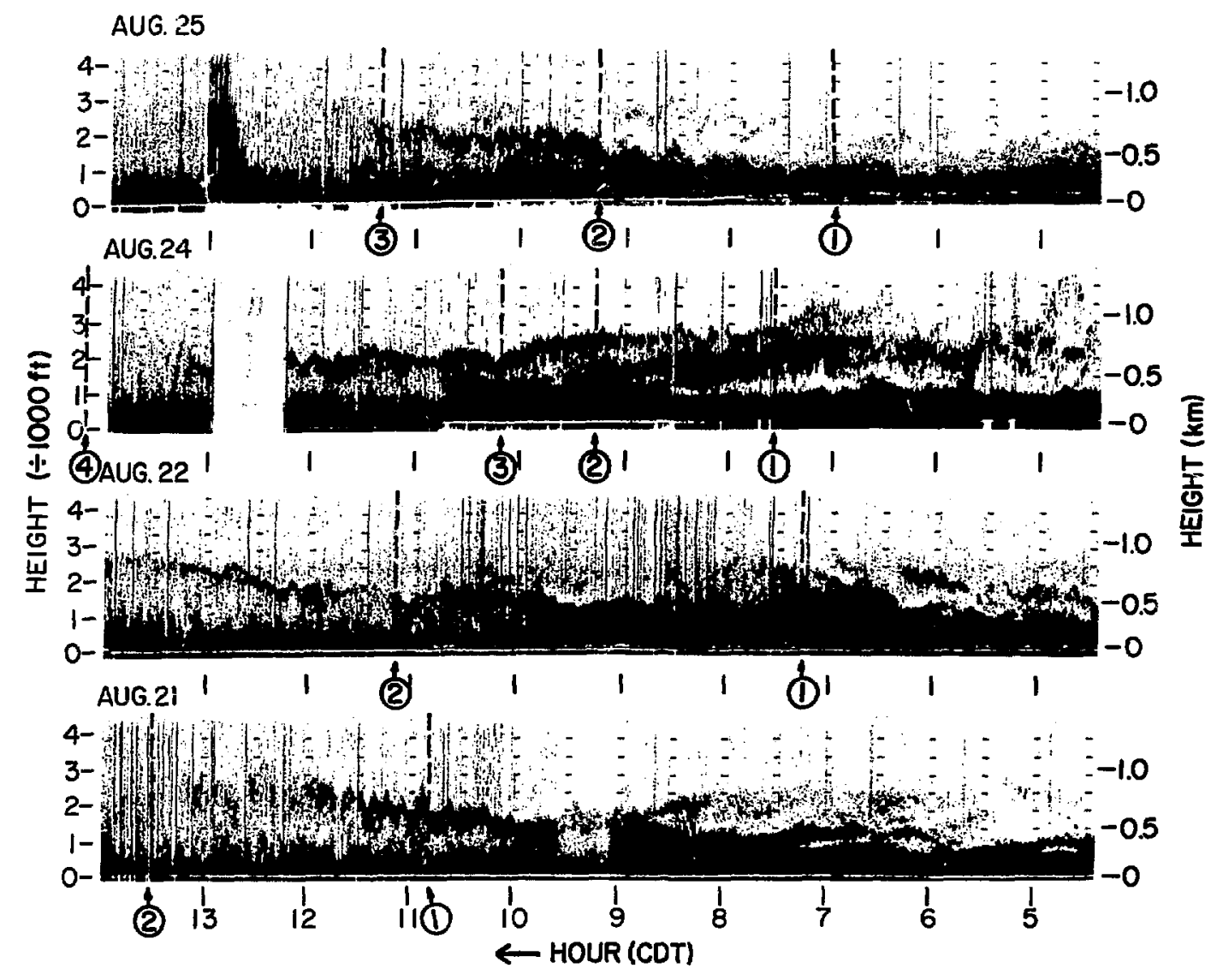

FIG . 5 - -Acoustic sounder records obtained at Granite City, near St. Louis, illustrating the moming breakup of the nocturnal inversion. Sunrise occurred at about $0620 \mathrm{CDT}$. [ANL Neg. No. 149-5506 Rev. 1]

about 1330. A gap in this record near noon resulted from a temporary power failure. Near 1100, the transmitted pulse length of the acoustic sounder was reduced and the receiver bandwidth was increased in order to improve the range resolution of the system; this emphasized the region of strong acoustic return from about $900 \mathrm{~m}$. Inspecticn of the profiles shows a weak temperature inversion of less than $1 \mathrm{C}$ at thls altitude. Serial radiosonde ascents show that this inversion slowly descended and weakened untll it was no longer detected jy the final sonde at 1430 . 

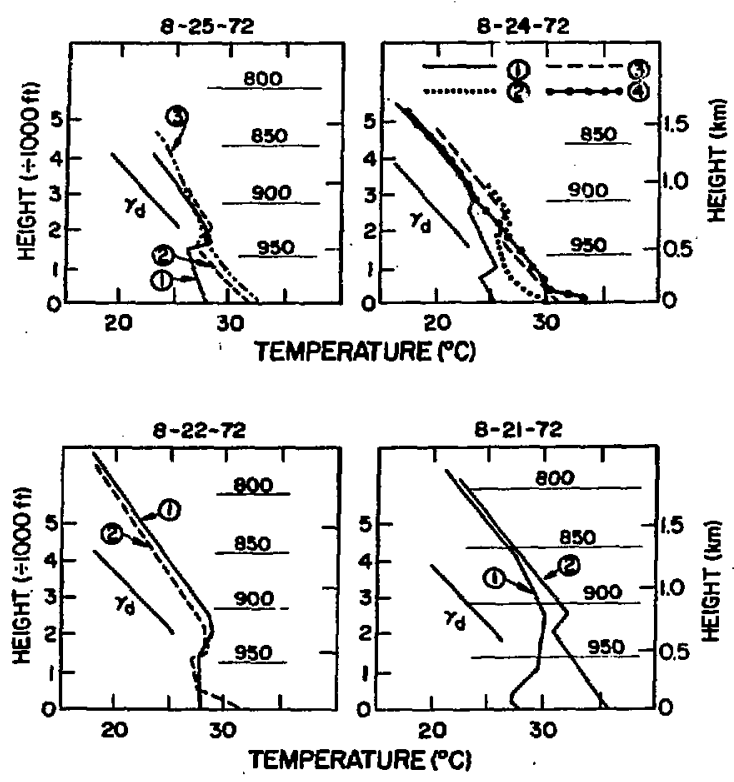

FIG . 6.--Results of serial radiosonde ascents corresponding to the observations of Figure 5. [ ANL Neg. No. 1495499 Rev. 2]
The remaining acoustic sounder records of Figure 5 show strong echo structures rising to about $900 \mathrm{~m}$, weakening and eventually dissipating near midday. Although the radiosonde ascents verify the rising Inversion structure, none of these examples corresponds very closely to the simple "morning-mixingheight" model discussed earlier. Apart from the example of August 21, a strong surface-based inversion had not been established prior to the 0700 radiosonde ascent.

It should be noted that, in some cases, ascending echo structures show well-defined periodic oscillations in the

inversion height, with peak-to-peak amplitudes between 200 and $400 \mathrm{~m}$ and periods between 7 and 30 minutes.

The acoustic sounder records of the Phase I type considered above are restricted to those occasions when a surface-based inversion that had developed during the night was eroded after dawn and eventually destroyed by the effects of solar heating introduced from below, rather than by a frontal passage or some other atmospheric event. On a few occasions when this set of criteria seemed to apply, the sounder records show the inversion breaking up in a series of bursts, Instead of as a steadlly rising layer. To illustrate this effect, Figure 7 shows two sounder records featuring a modified transition from night to daytime conditions. The upper example indicates that regions of strong echo developed from $500 \mathrm{~m}$ up to $1 \mathrm{~km}$ in five bursts which occurred at regular intervals of 20 minutes. Records of surface temperature and solar radiation appear normal and do not reflect this periodicity. Similarly, the bottom record of 


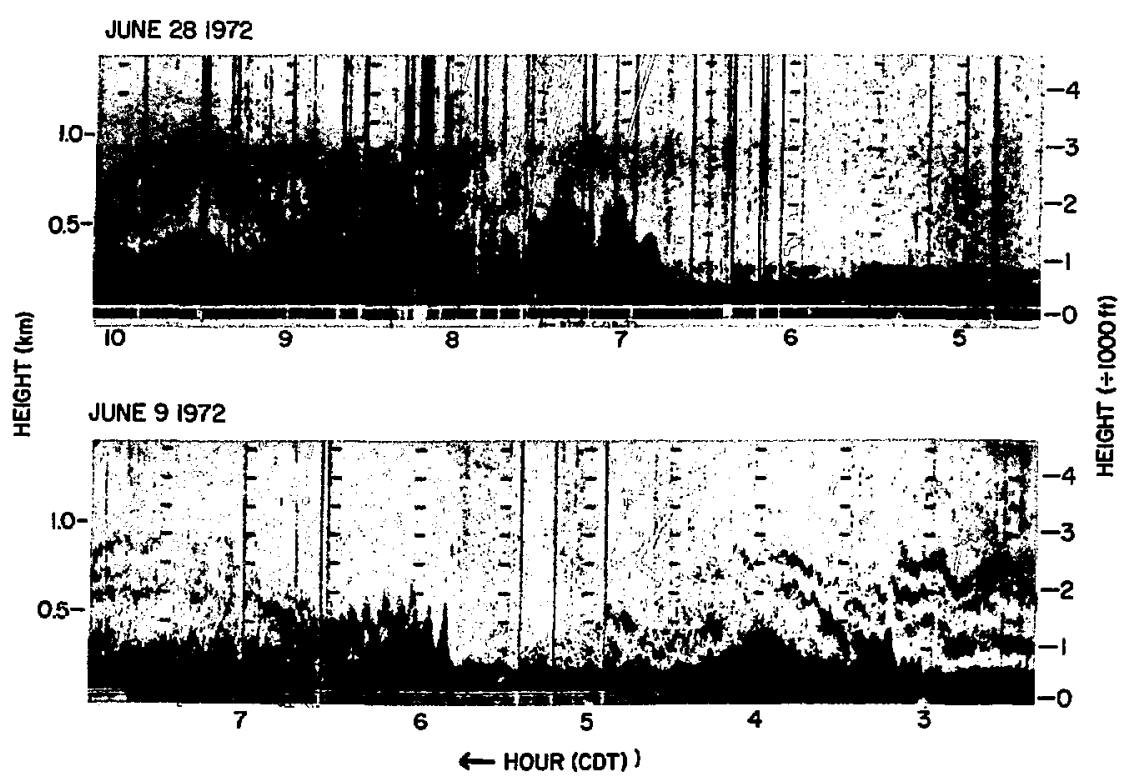

FIG. 7.--Sounder records lllustrating the periodicitles associated with the breakup of the noctumal inversion. [ ANL Neg. No. 149-5478 Rev. 1]

Figure 7 shows a sudden onset of at least seven bursts of strong echo, each extending to more than $600 \mathrm{~m}$, that occurred at regular Intervals of about 5 minutes. These regions of strong echo would seem to have been related to discrete regions of convective activity rather than to breaking waves that formed on an established inversion layer. Earller sections of both records in Figure 7 display some unusual features: the upper case shows a constantrange return at a slightly greater altitude than the normal low-level echoes and is indicative of clutter, while the lower example shows a multllayered structure undergoing rapid and irregular helght changes within short time intervals.

\subsection{Phase II. Daytime Convective Plumes}

During the late morning and early afternoon of clear, sunny days, unstable lapse rates develop through the lowest few tens of meters. At some helght above the surface, the assoclated upward fluxes of sensible and latent heat become organized into buoyant plumes which ascend through the lowest 
few hundred meters until adiabatic cooling and entralnment with cooler surroundings reduces the excess temperature of air within the plumes and buoyancy is reduce and eventually lost. This simiplifled plcture of organized convective exchange forms the basis of a simple model for considering the nature of typical daytime acoustic sounder records.

Within the warmer ascerding plume (more particularly, in the zone between the ascending warm and descending cooler air), there exists considerable turbulence having a probable "outer" scale size of the order of the plume diameter, and certainly containing turbulence comparable in scale size to the half-wavelength of the sounder's transmitted acoustic waves (approximately $15 \mathrm{~cm}$ ). If this tarbulence were sufficiently intense to produce strong spatial Irregularities in the temperature field, the radiated acoustic pulse would be strongly scattered and relatively large echoes would be detected by the receiver.

Figure 8 presents two records obtained at Argonne during May 1972. The first example shows the nocturnal inversion in the final stages of breakup. As the layer echo ascended from $200 \mathrm{~m}$ to $500 \mathrm{~m}$, the echo intensity diminished and finally disappeared at about $1000 \mathrm{~m}$. About this same time or slightly earlier the sounder record changed to the typlcal daytime "grass" type of pattern featuring predominately vertical echo structures that apparently originate near the surface. Observations of such echoes have been reported by Beran et al. (7) who measured the Doppler shift of the signsils recelved and showed that the region of strongest return (darkest printing) corresponded to ascending plumes and shear zones, while the patches of very weak echo (light or zero printing) were assoclated with slowly descending air. Figure 8 shows that individual patches of strong echo last for about 5 to 10 minutes, extend in hetght to about $500 \mathrm{~m}$, and begin to lose intensity as the patterns taper to a pointed cap (the signal strengths having been approximately compensated for beam divergence). The records suguest that, with the prevalling mean wind speeds of about $1.5 \mathrm{~m} \mathrm{~s}^{-1}$, these plumes would have had horizontal dimensions of about $500 \mathrm{~m}$ near the surface.

Acountlc sounder records of daytime convective activity indicate tha: the greatest heights attained by the largest plunes define an envelope whose 


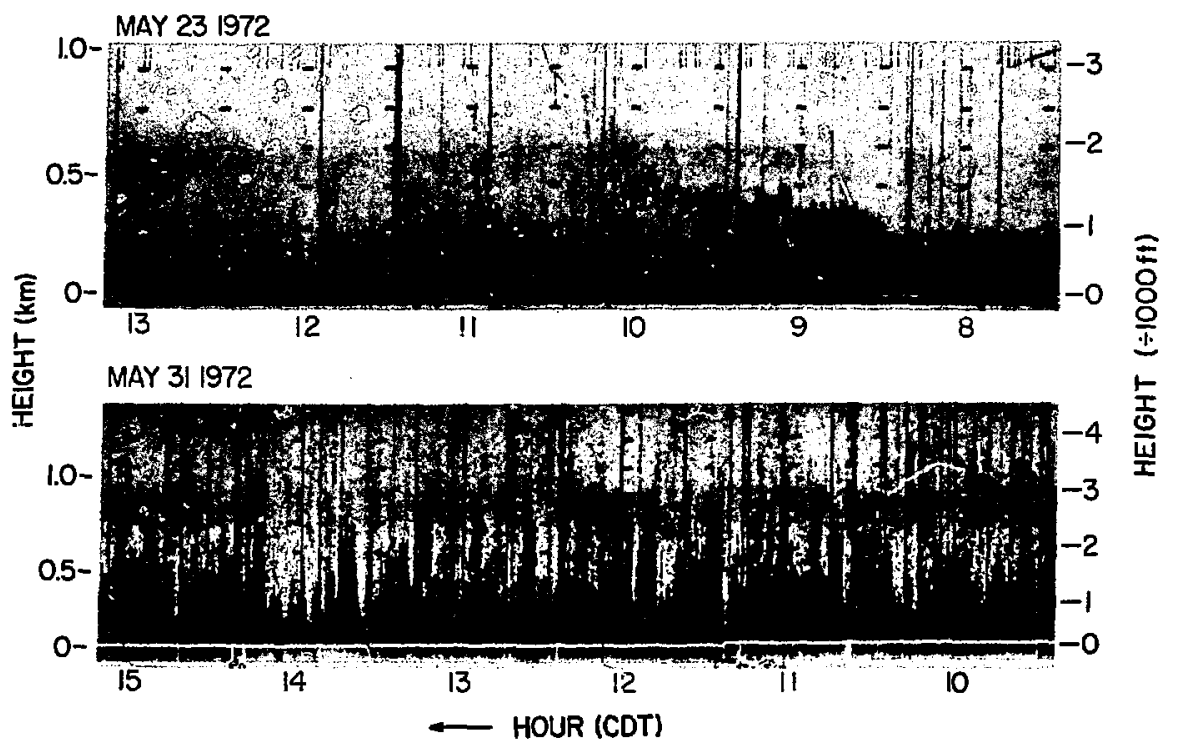

FIG . 8.--Typical daytime acoustic sounder patterns of convective plumes. [ANL Neg. No. 149-5474 Rev. 2]

altitude is greatest during the early afternoon. The actual plume circulations robably extend somewhat higher than do the observed echoes since weaker scoustlc returns from longer ranges are eventually lost in background noise. जreater acoustic power eventually may be used to verlfy that the plumes extend :o greater heights than is apparent in the present observations. Records obtained it Chlcago and St. Louls through 1972 show that plumes typically ascend to sbout $1 \mathrm{~km}$; during the summer months in Australla, however, similar equipment las detected plumes extending above the 2-km level.

Since thermal plumes are important agents in the transport and dispersion f pollutant materials released near the surface, thelr behavior as a function of ynoptlc situation, topography, and position with respect to the urban heat iland is worthy of more detalled study.

\subsection{Phase III. The Decay of Convective Activity and Re-Establish- ment of the Nocturnal Inversion.}

Towand sunset, thermal plume activity diminishes and the envelope of te tallest plumes descends to less than $300 \mathrm{~m}$. Soon after dusk, the sounder 


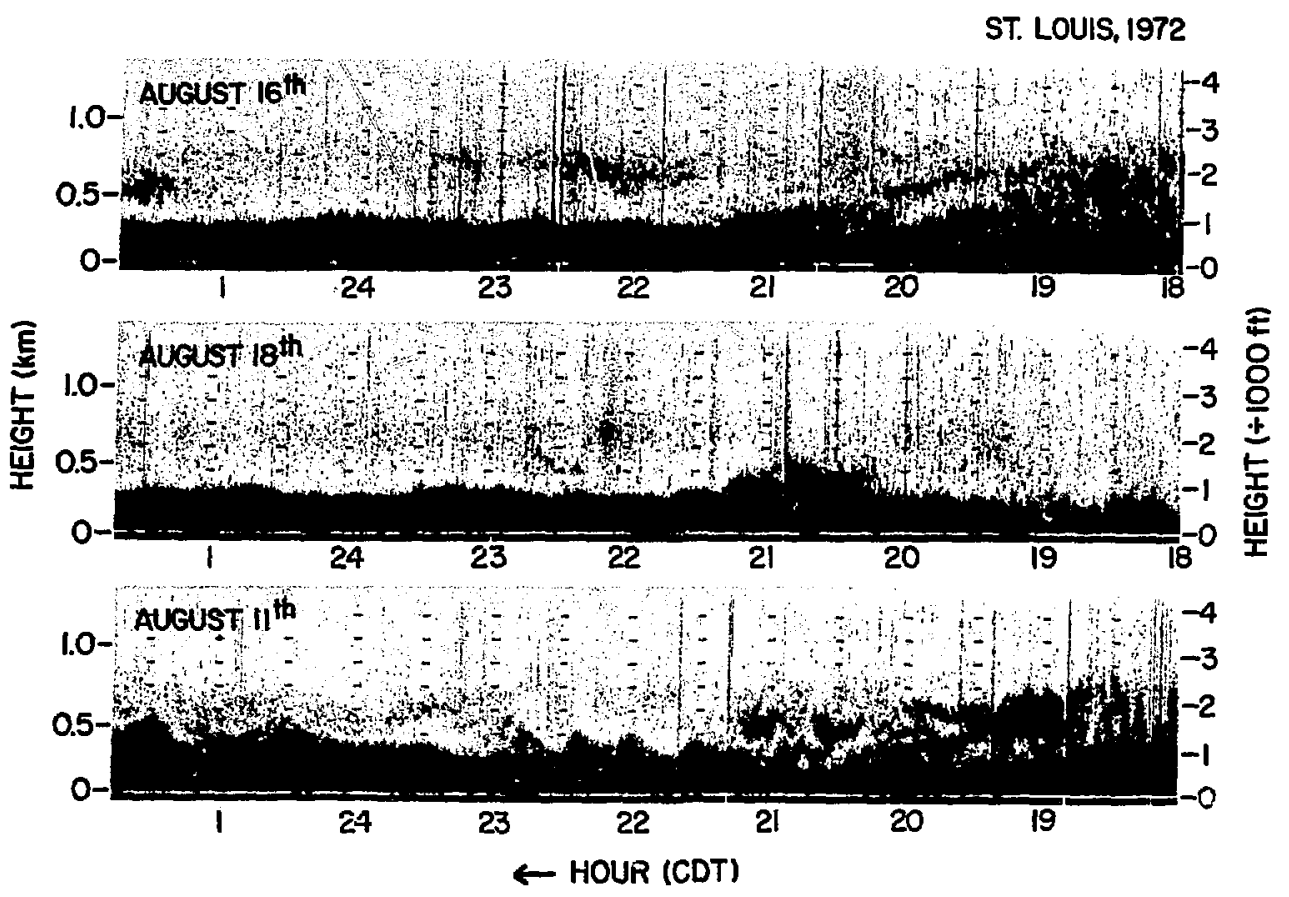

FIG. 9.--Examples of the decay of plume activity and the establishment of ypical nocturnal patterns. [ANL Neg. No. 149-5470 Rev. 1]

records change character and begin to show strong short-range echoes having an abrupt but almost unlform upper limit, typically near $250 \mathrm{~m}$. With normal jain settings, the facsimile recorder falls to reveal detalled structures within hils region of strong echo, but the relative signal strength is usually slightly jreater at the top edge of the echo band. Figure 9 presents three sounder ecords illustrating the decay of convective activity and the formation of patoms representative of the type usually observed throughout the night. Although 11 of the examples of Figure 9 were obtained during the St. Louls (Granite ity) experiment, " simllar recozds were obtained at Argonne throughout the ear. The August 11 recond lllustrates an oscillatory behavior often observed

Acoustic sounding program conducted near St. Louls as part of the METROMEX xperiment of 1972 . 
night (In this example, between 2100 and 2300). Frequently, a very weak ifuse band of echoes develops above the stronger echo region; examples of is are evident in two of the traces of Figure 9 (August 11 and 16).

Further evidence of multilayered structures and oscillatory motions of yersion layers in the lowest kllometer of the atmosphere is displayed in jure 10. The sounder record obtalned on August 20 at about 0400 shows a arply defined reglon of strong acoustic return at an elevation near $300 \mathrm{~m}$. is return appears to be no deeper than the length of the transmitted acoustic lse (40 $\mathrm{m}$ in this case, as indicated by the dark band at the bottom edge of ch record). Although a radiosonde was not launched on this occaslon, preous observations of this type ${ }^{(2-4)}$ have shown that a shallow, but strong, nperature inversion exists at the height of such a "one-pulse" echo. An tstanding characteristlc of such situations is the presence of an extremely ge temperature gradient near the base of the inversion layer.

An earlier section of the same sounder recond (top, Figure 10) shows unusally rapld change in the echo structure with some vertical developmeni m a helght of $30 \mathrm{~J} \mathrm{~m}$ to nearly $1 \mathrm{~km}$ within a 30 -minute period, followed by a -minute long period of recovery to the original situation. Throughout this e the surface winds were light, but significant changes in direction occurred. or to midnight, winds were north to northwesterly, but midway through this ini (about midnight) the wind rapidly backed to a southerly direction (via the st); subsequently the winds veered to northerly again at the same time that echo layer returned to a position nearer the surface (about 0100). It is bably significant that the more southerly flow came from the direction of the tral city area of St. Louls, rather than from the rural and suburban areas to north. Thus this period of a disturbed, elevated inversion may represent passage overhead of a portion of the urban heat lsland dome.

The bottom trace to Figure 10 (obtained at Argonne on May 17, 1972) is a strong layer-type echo, the leading edge of which is markedly oscilry. Later in the same recond, this echo band slowly ascended, weakened, disappeared. Throughout this period, a combination of light winds and a ng low-level inversion maintained poor conditions for the dispersion of 


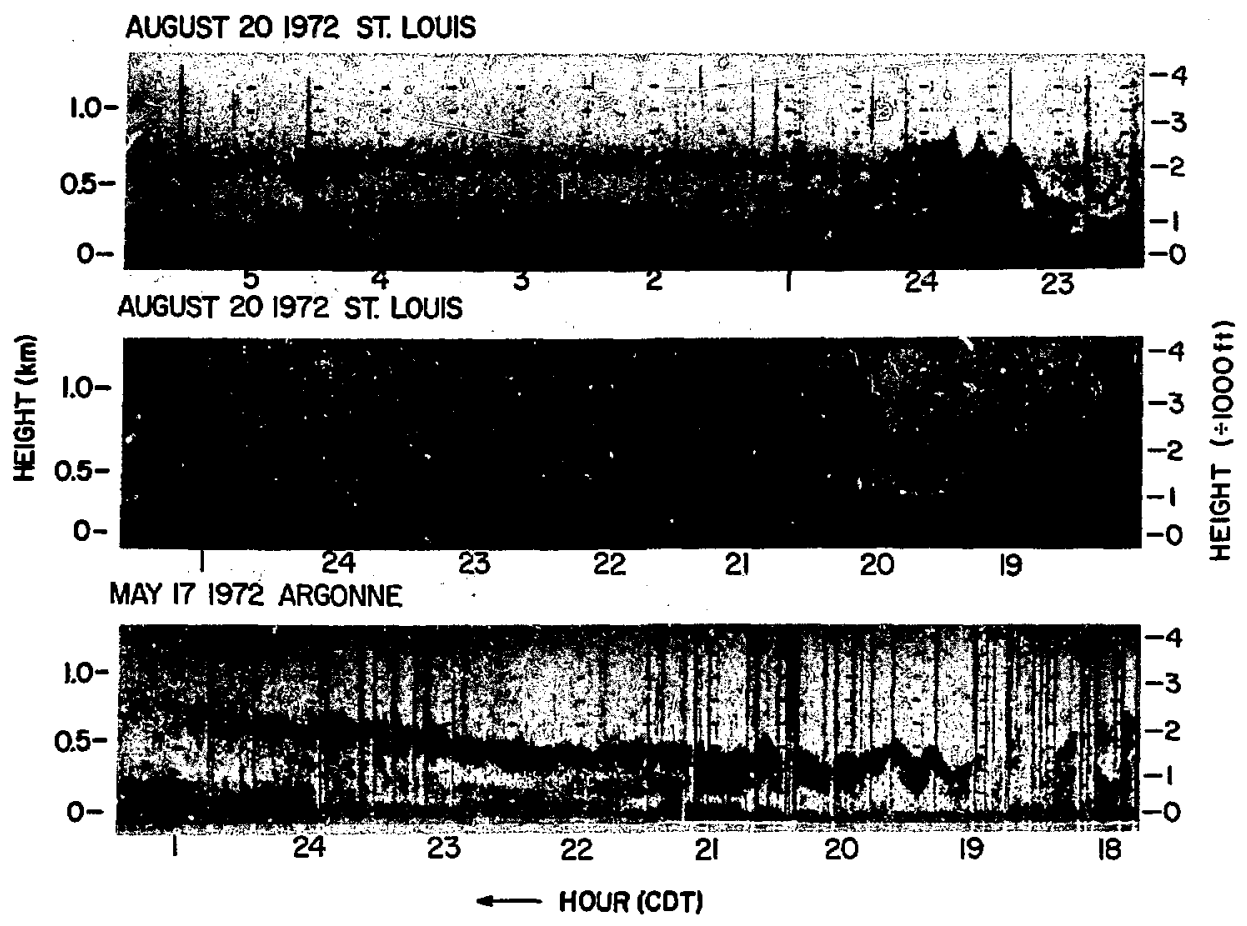

FIG. 10.--Strong, multilayered inversions sometimes observed at night. [ ANL Neg. No. 149-5472 Rev. 2]

atmospheric pollutants, and both the city and suburban areas of Chicago were subjected to severe air pollution. Statistics supplied by the Chicago Environmental Control Board showed that during the period of May 17 to 18, the second highest pollution of the month was recorded; suspended particulate concentrations were approximately twice the average for the month, carbon monoxide concentrations were $50 \%$ above average and the coefficient of haze Index was about 60\% more than average (with the averages based on measurements made at 20 jampling stations in the Chicago area).

Similar conditions of strong atmospheric pollution existed during the 3t. Louis experiments when the acoustic sounder displayed marked low-level itratifications throughout the right (as in Figures 9 and 10).

3.4 Overall Vlew

Having discussed in some detail the major phases of the diurnal cycle 
the atmospheric mixing layer, we can consider a single 24-hour acoustic inder record displaying all three aspects. Figure 11 shows a record obtained June 17, 1972, in light to moderate surface winds with clear skies. A slowving high-pressure system was located over the Chicago area during the iod, and the sounder record obtained on the previous day is similar to that Jwn here. Although the record of Figure 11 clearly shows a decline of zse II convective activity and the re-establishment of a typlcal Phase III sturnal pattern, an elevated echo layer also developed near $400 \mathrm{~m}$ and slowly scended to about $100 \mathrm{~m}$ by midnight. It is tentatively suggested that this zvated inversion might have been associated with an urban-rural circulation aracterized by ascending, warmer air over the city that is necessarily supplied low-level divergence, and compensated by a corresponding descending, $\checkmark$-level divergent flow over the surrounding country areas. The latter circulan could have formed a subsidence inversion over the rural site of the acoustic mder.

In the example shown in Figure 11, the upper limits of the afternoon rmal plumes are marked by patches of stronger echoes which may have been oclated with the presence of small cumull that formed at the tops of the most ive convective plumes. The release of latent heat by the condensation of er vapor carried aloft in thermal plumes would create localized regions of ill-scale temperature irregularities, areas which could be detected by an ustic sounder. Small cumuli were indeed observed on this particular occa3, developing late in the morning and existing throughout the day. However, early morning was cloudless, and surface heating was rapid.

Other Features of Acoustic Sounder Records

\subsection{Strong Elevated Inversions}

Figure 12 shows two examples of sounder records in which strong returns ? detected from altitudes above $1 \mathrm{~km}$. The upper record charts a discrete $r$ of depth corresponding to about one pulse length which appears abruptly jout $1300 \mathrm{~m}$ and then gradually descends to below $1 \mathrm{~km}$ over a period of sal hours. Typical daytime convective activity is evident below this year. te second example the elevated layer echo ascends slowly from about $800 \mathrm{~m}$ 


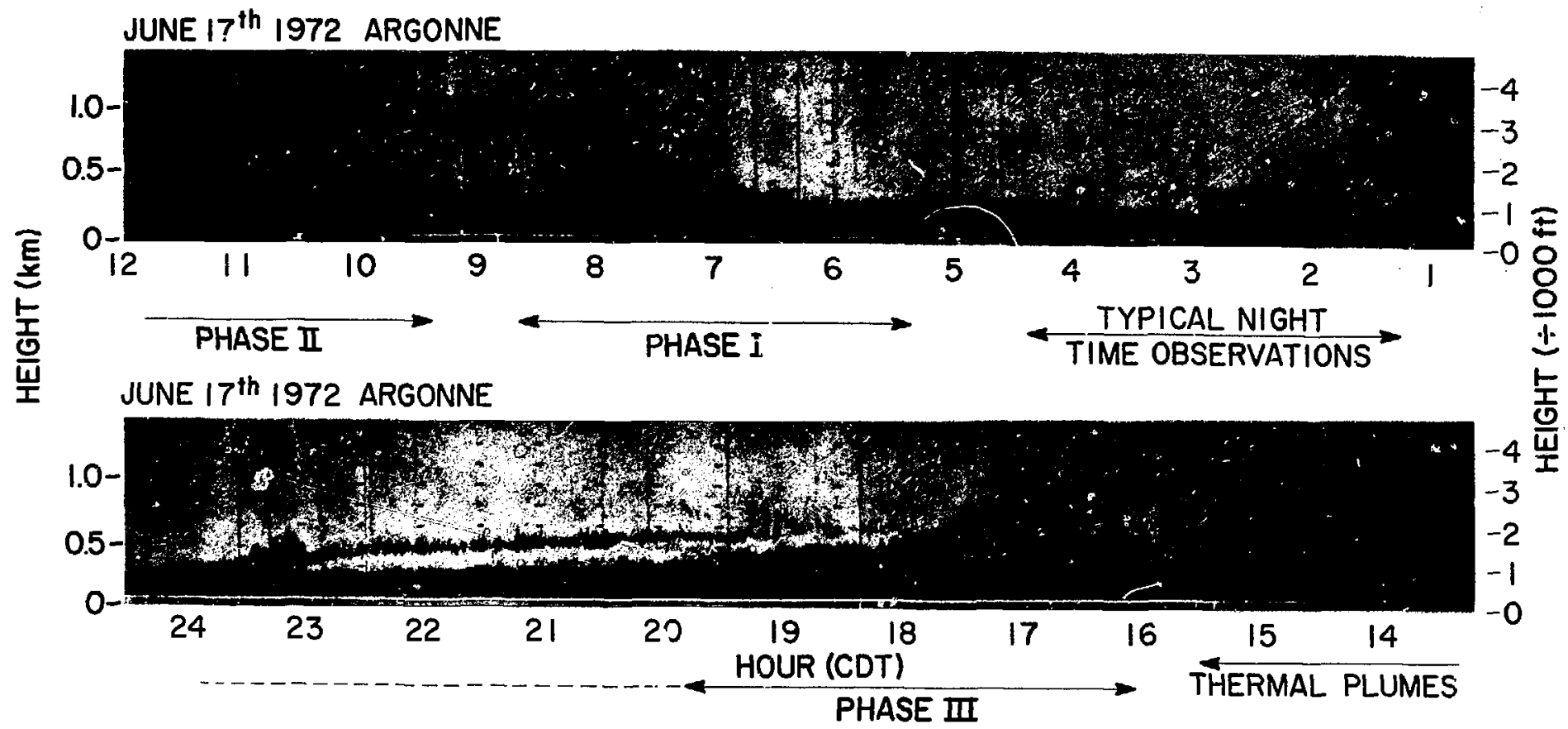

FIG. 11.--A typical diurnal variation of the atmospheric mixing layer. [ANL Neg. No. 149-5472 Rev. 2] 


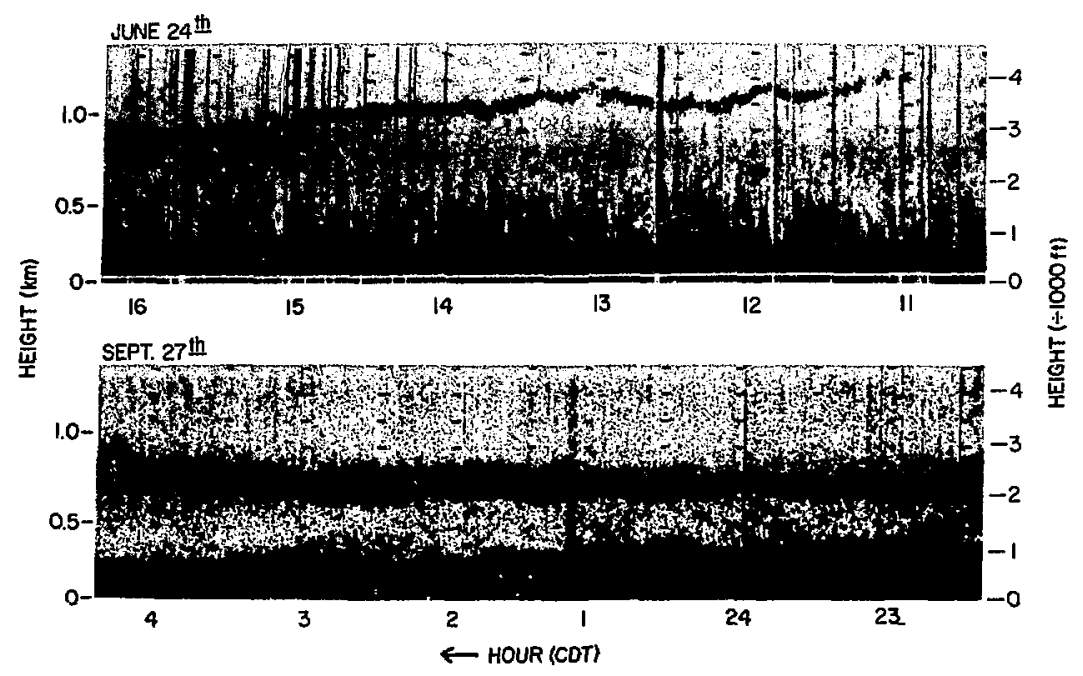

FIG. 12.--Examples of elevated inversions detected at Argonne. [ANL Neg. No. 149-5480 Rev. 1]

to above $1 \mathrm{~km}$, but unlike the earlier example, the scattering region is always several pulse lengths deep. This echo is associated with the base of a temperature inversion with a magnitude of about $6 \mathrm{C}$ as measured by several radiosonde probes. As shown elsewhere, ${ }^{(4)}$ the thickness of the echo region appears to vary inversely with the gradient of potential temperature near the base of the inversion; thus, thinner scattering regions are associated with stronger gradients.

\subsection{The Passage of a Cold Front}

Figure 13 is a sounder record obtained when a strong frontal zone and assocated rain passed over the sounder site. In this example the upper limit of strong acoustic returns suddenly increased from $300 \mathrm{~m}$ to about $1100 \mathrm{~m}$ at 2000. During the next two hours an organized pattern began to develop; after 2200 the general appearance of the record deteriorated rapidly as rain showers began to generate noise at the recelving antenna.

The corresponding surface temperature, lapse rate and wind direction charts have been included in Figure 13 to assist the interpretation of this case. During the first hour after the iront passed, the surface temperature decreased by about $6 \mathrm{C}$. Records of the temperature differences through the lowest $50 \mathrm{~m}$ 


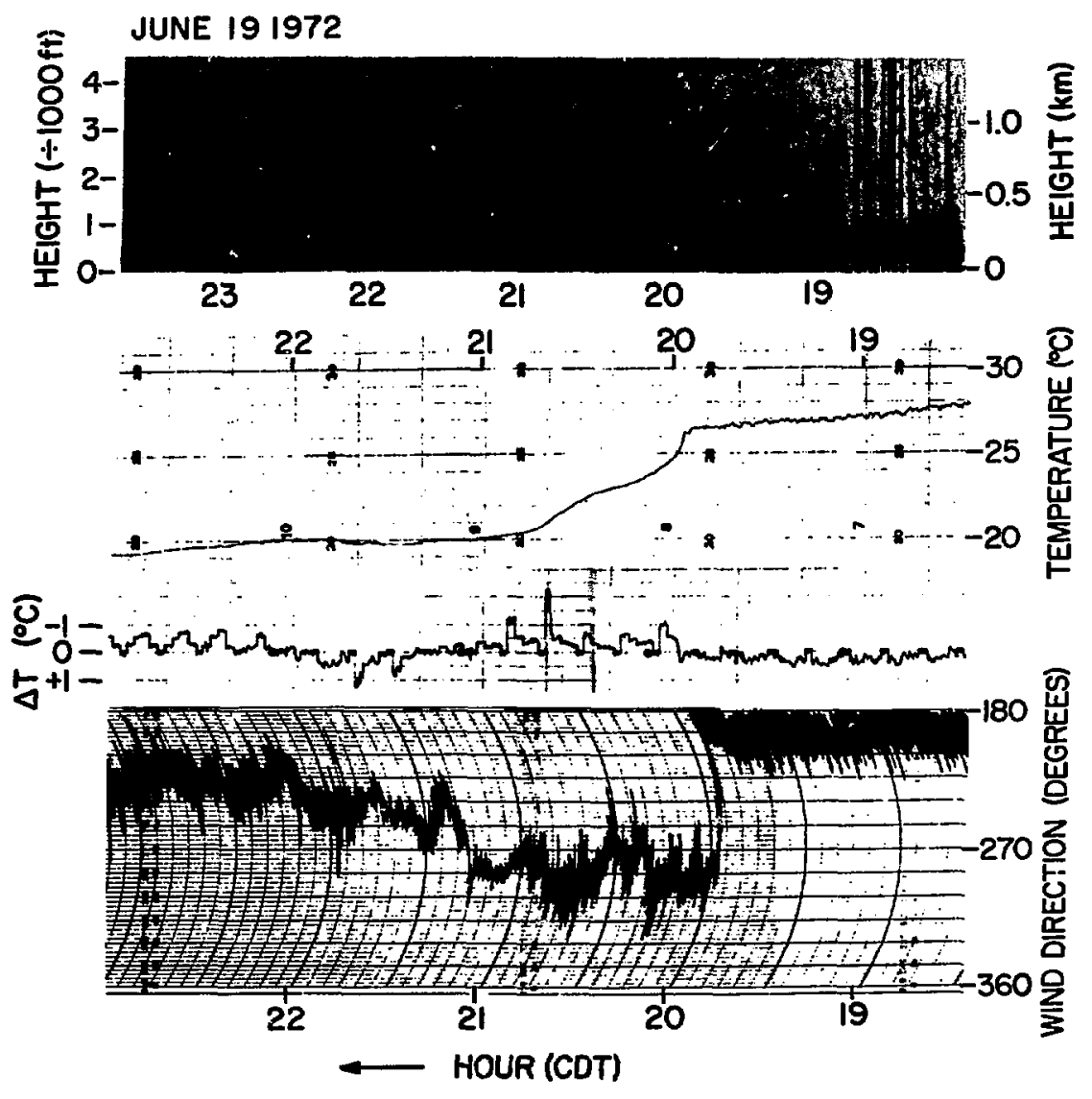

FIG. 13.--Typical records of a strong cold front passage. For $\Delta T$, the vertical helght differences sequence through $0,4,8,20$, and $44 \mathrm{~m}$, approximately. [ANL Neg. No. 149-5482 Rev. 2]

of the atmosphere indicate a change from a slightly stable to an unstable lapse rate when the cooler air arrived at about 2000. The frontal passage was also marked by the usual cyclonic wind shift, in this case from southeast to northwest through the west.

\subsection{The Passage of a Dry Squall Line}

In several ways the sounder record of Figure 14 resembles the example presented in Figure 13. In particular, the helght of the strong acoustic returns increased by a factor of more than four within two minutes. Close inspection 


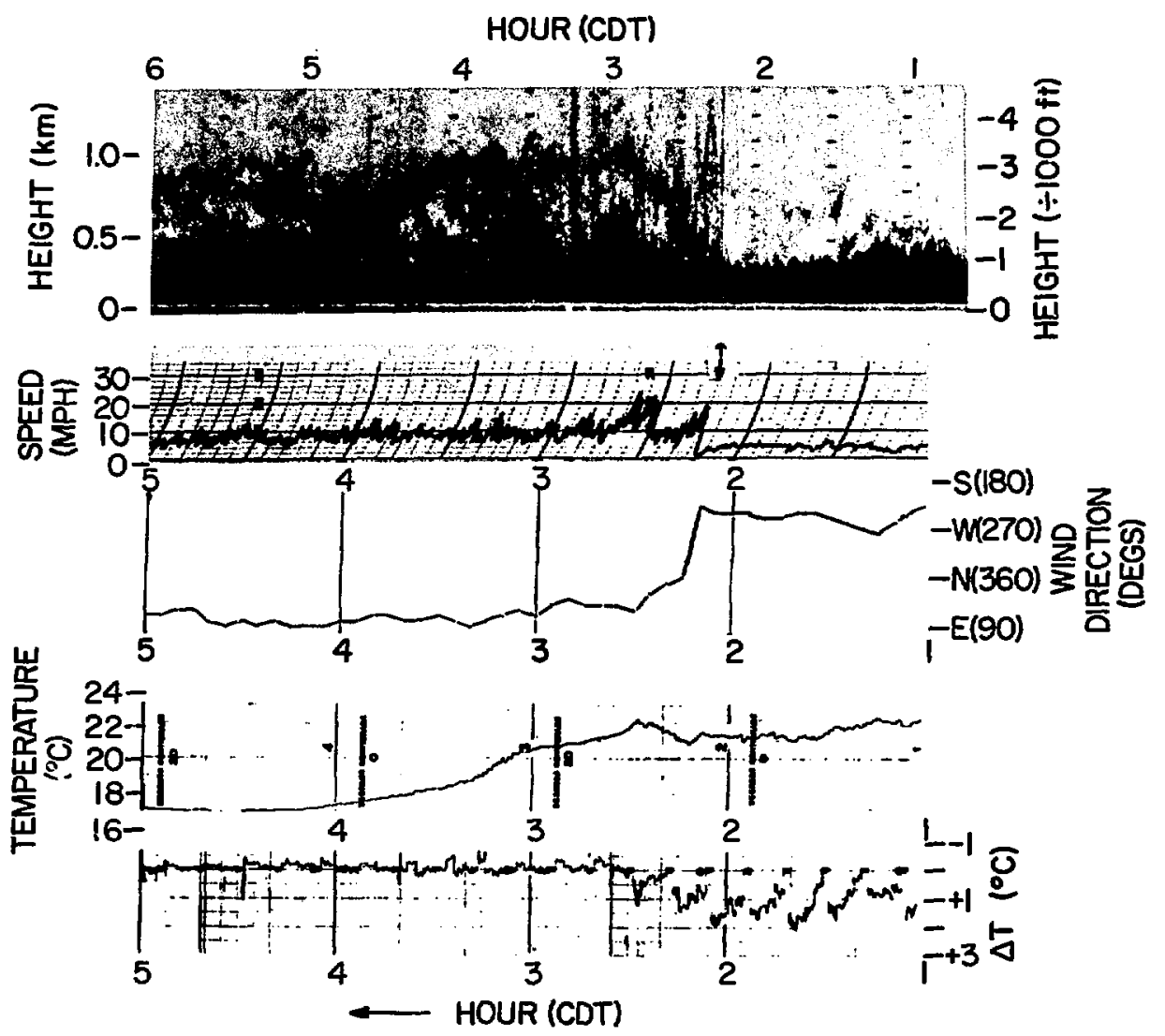

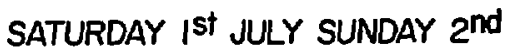

FIG. 14.--Typical records of a dry squall line passage. For $\Delta T$, the height differences are the same as in Figure 13. [ANL Neg. No. 149-5416 Rev. 2]

of this example shows an extremely sharp "spike" in the facsimile pattern at 0215, followed by a perlod of diffuse echoes extending above $1 \mathrm{~km}$. Finally, a pattem of multllayered structures evolved at about 0400 .

Precisely at the time of the "spike" in the acoustic record, the wind speed suddenly increased from near calm to $9 \mathrm{~m} \mathrm{~s}^{-1}$ (from 1 to $20 \mathrm{mph}$ ), while the direction veered from southwest to north within minutes and then continued a clockwise rotation until finally settling in from the east. A mlcrobarograph recorded a sudden pressure increase of $1.2 \mathrm{mb}$ at the onset of this event, and a detalled surface pressure chart indicated that a squall line was in the 


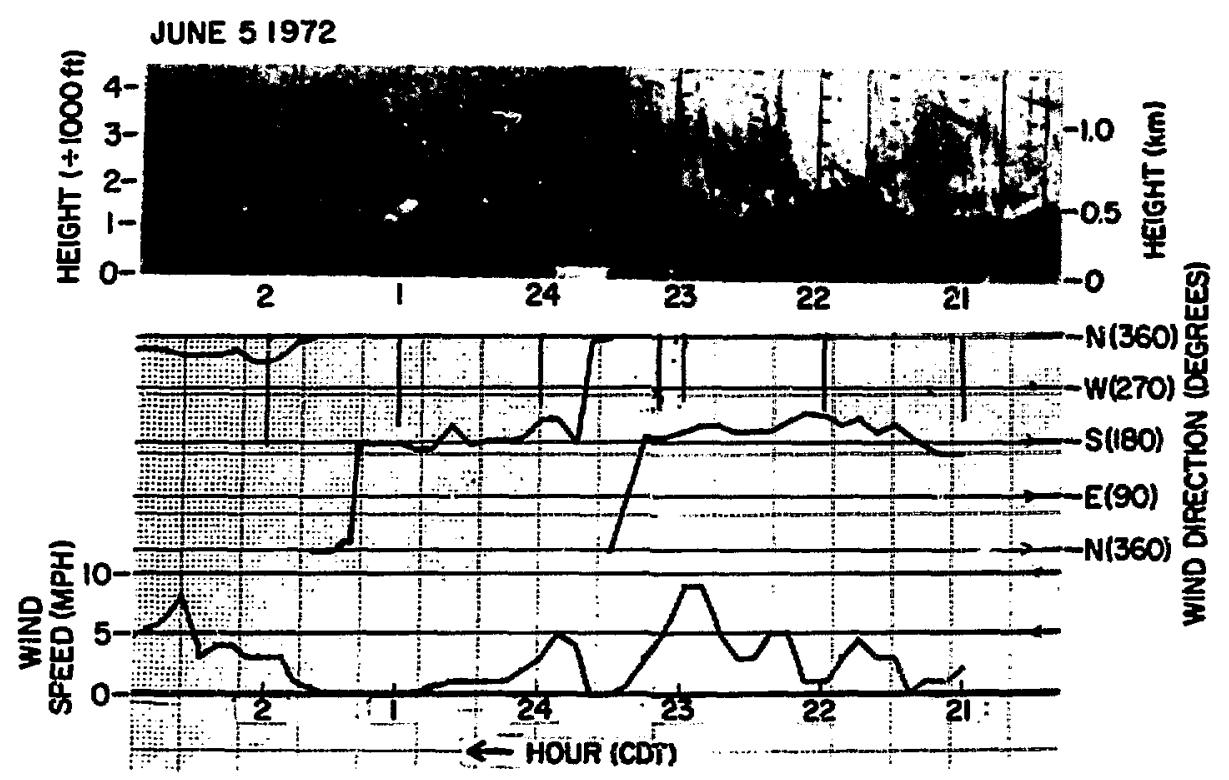

FIG. 15.--Typical records of a thunderstorm passage. [ANL Neg. No. 1495483 Rev. 1]

vicinity. However, no rain was recorded during this period.

Unlike the previous example, the event shown in Figure 14 was associated with a small surface temperature increase of about $1.5 \mathrm{C}$. Finally, the low-level lapse rate data show that a strong, surface-based inversion which had existed prior to 0215 was rapidly replaced by a near-neutral proflle. Apparently, at the onset of the squall, strong turbulence mixed a deep layer of air, thus destroying the low-level inversion and causing the temperature near the surface to increase slightly. For future studies, analysis of Doppler shifts in the frequency of the acoustic signals would make it possible to investigate the nature of the vertical notions associated with the passage of such squall lines.

\subsection{Cross Section of a Thunderstorm}

Many thunderstorms passed through the Chicago area during 1972, and a variety of associated acoustic sounder records was obtained. One particular event is presented in Figure 15. Beginning at 2100, a layered echo structure 
ascended srom the region of strong short-range echoes to reach an altitude of about $1 \mathrm{~km}$ within 2 hours. Just prior to midnight a 20 -minute period of intense acoustle nolse was reconded during a hoavy downpour of rain. After the rain a double echo layer formed and was observed to descend steadily for the next 1.5 hours to only a few hundred meters above the suiface.

Throughout the storm wind speeds were relatively llght (generally less than $5 \mathrm{~m} \mathrm{sec}{ }^{-1}$ ), but two significant wind direction changes were observed. During the passage of the storm center, the wird direction changed through 360 deg in a counterclockwise direction in lese than 30 minutes. When the descending echo layer a: the tralling edge of the storm came close to the surface, the wind backed $180 \mathrm{deg}$, switching from the south through east to the north. This sequence suggests that a single thunderstorm cell surrounded by a weak cyclonic circulation had mosed slowly past the site.

The ascending and descending traces recorded during this event represent echoes from temperature inversions that were probably created in the following manner. After downdrafts in the center of the thunderstorm brought down both rain and cold alr, the flow diverged radially at the surface to produce a "micro-cold front." Advancing outward, this front forced the warmer air surrounding the storm to ascend, thus creating an elevated Inversion. As the storm system moved slowly across the sounder slte the vertlcal cross section shown in Figure 15 was produced.

Interpreting acolistic sounder records with the assistance of only a few surface meteorological observations can be difficult and often misleading, but the preceding events seem to fit the classical model of an isolated thunderstorm cell as described in many texts (e.g. Ref. 8).

\subsection{The Nocturnal Elevated Layer}

On a few occasions throughout the year, an elevated, layer-type echo structure was observed to form prior to midnight and to last from four to six hours. Figure 16 shows that on the night of June 22, such an echo gradually ormed near $600 \mathrm{~m}$, descended to $500 \mathrm{~m}$ and then ascended and disappeared Ifew hours later. Of special interest is the fact that the usual surface-based locturnal inversion did not form until the upper layer started to break up, even 

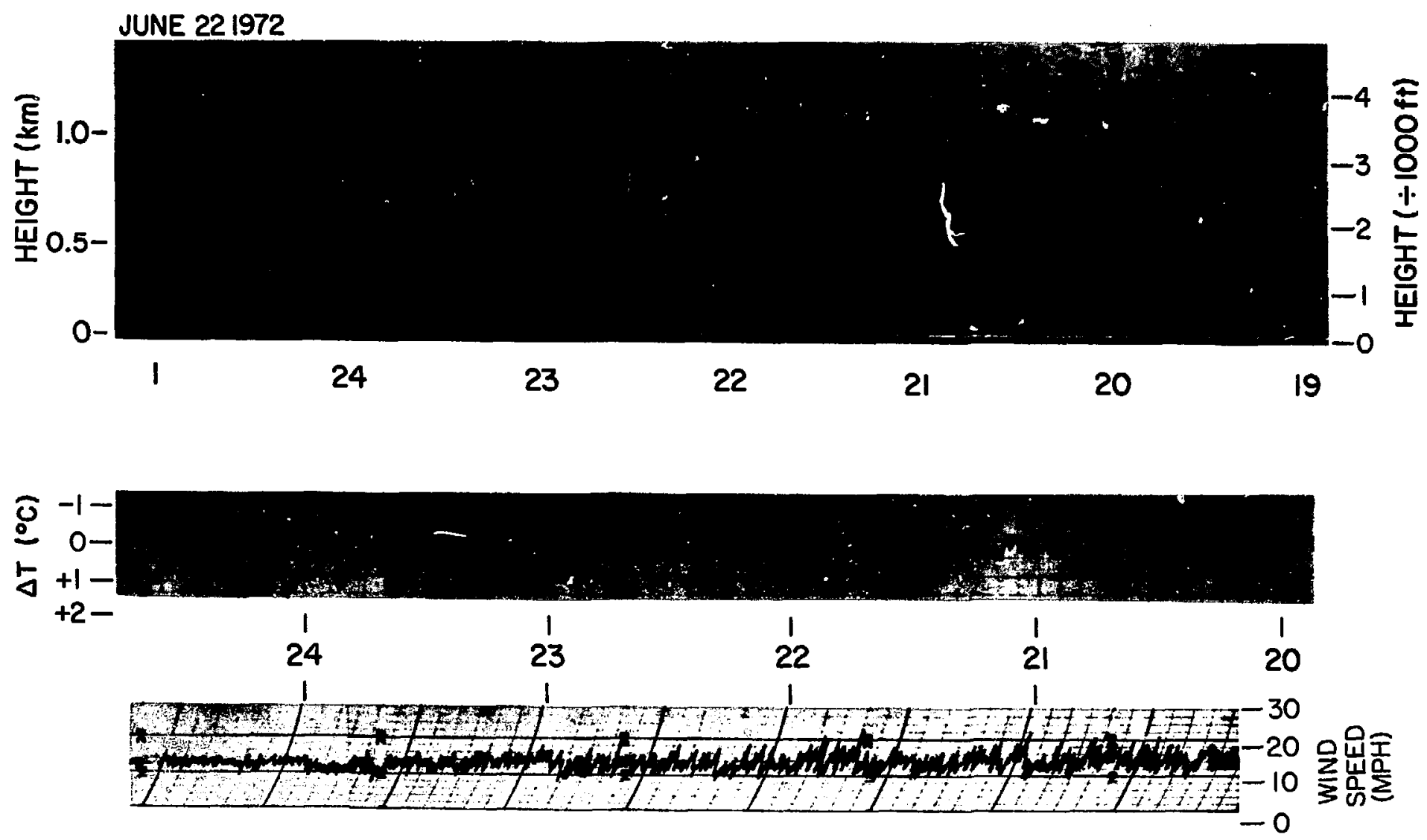

$\longleftarrow$ HOUR (CST)

FIG. 16.--Development of a nocturnal elevated layer. For $\Delta T$, the height differences are the same as in Figure 13. [ANL Neg. No. 149-5479 Rev. 1] 
though skies were clear. The lapse rate data in Figure 16 show that a weak surface inversion existed until 2330 but that this rapidly strengthened into a temperature increase of $2 \mathrm{C}$ over $50 \mathrm{~m}$ after the upper layer dissipated. With the increased stabllity in the lower layers, there is a corresponding decrease in turbulent velocity flucturations in the wind speed record.

\section{Conclusion}

Even in the absence of significant changes in surface weather patterns, the lower layers of the atmosphere undergo a regular diumal cycle which, in this discussion, has been considered in three stages. For each phase of the development, examples of typical acoustic sounder records have been presented. In particular, it has been shown that, during the morning break up of the nocturnal inversion, continual re-evaluation of the mixing height is preferable to using the single "morning mixing height" model based on the minimum temperature before sunrise alone. The acoustic sounder records were used to establish the height of the temperature Inversion base throughout the morning, and predictions of the simple model were compared with this developing structure. In addition, multiple radiosonde soundings obtained over a sounder site near St. Louis have been used to compare measured temperature proflles with the echo structures recorded by the sounder. Once again these measurements have shown that regions of stronger acoustic return are related to anomalies in the temperature proflles and, in particular, that elevated layer-type echoes are associated with temperature inversions. Typical acoustic sounder records associated with daytime convective plumes were briefly discussed, and the decay of plume actlvity near sunset followed by the re-formation of the nocturnal inversions have been considered, reference again being made to approprlate acoustic sounder records .

An understanding of the normal development of the atmospheric mixing layer is of considerable value to air pollution meteorologists, and the usefulness of acoustic sounding techniques for routine monitoring, as well as detalled study of these lower atmospheric structures, has been demonstrated in inis report. 


\section{Acknowleqment}

The author is grateful for the assistance given during the preparation of this report by P. Frenzen, B. B. Hicks, M. L. Wesely and E. L. Miller of Angonne National Laboratory. The field experiments were conducted with the assistance of F. A. Žerbe and F. C. Kulhanek. 


\section{References}

1. McAllister, L, G., J. R. Pollard, A. R. Mahoney, and P. J. R. Shaw. Acoustic sounding -a new approsch to the study of etmospheric structure. Proc. I.E.E.E. 57, 579-587 (1969).

2. Bourne, I.A. and N.A. Shaw. A preliminary report on acoustic scunding of the lower atmosphere. RAAF Academy Research Report No. 55, University of Melboume, Australla (1970).

3. Bourne, I.A. and N.A. Shaw. Acoustic sounding in a troplcal envrlonment. RAAF Academy Report No. 83, Unlversity of Melboume, Australla (1971).

4. Shaw, N.A. Acoustic sounding of the atmosphere. Ph.D. Thesis, University of Melbourne, Australla (1971).

5. Shaw, N.A. Acoustic sounding of the lower atmosphere. Argonne National Laboratory Radiological and Environmental Research Division Annual Report, January-December 1971. ANL-7860, Part IV, pp. 206-212.

3. Russell, P.B., E. E. Uthe, F.L. Ludwig and N.A. Shaw. A comparison of atmospherlc structure as observed with monstatic acoustic sounder and lidar techniques. J. Geophys. Res. 79, 5555-5566 (1 974).

' Beran, D.W., C.G. Little, and B.C. Willmarth. Acoustic Doppler measurements of vertical velocities in the atmosphere. Nature $\underline{230}$, 160-163 (1971).

3. Byers, H.R. General Meteorology. McGraw Hill Book Co., Inc., New York 3rd Ed., 1959, pp. 458-468. 


\section{Ippendix}

Although placing the acoustlc antenna in a hole in the ground provides 3 superior method for reducing side lobes, the arrangement results in a fixed nstallation that requires periodic maintenance, especially after a heavy rain as partially filled the hole. To take advantage of the inherently portable ature of the acoustlc sounder system's light-weight antenna and compact lectronic package, an acoustic baffle or "cuff" surrounding the antenta was egigned and constructoú on a small traller.

The side-lobe suppression

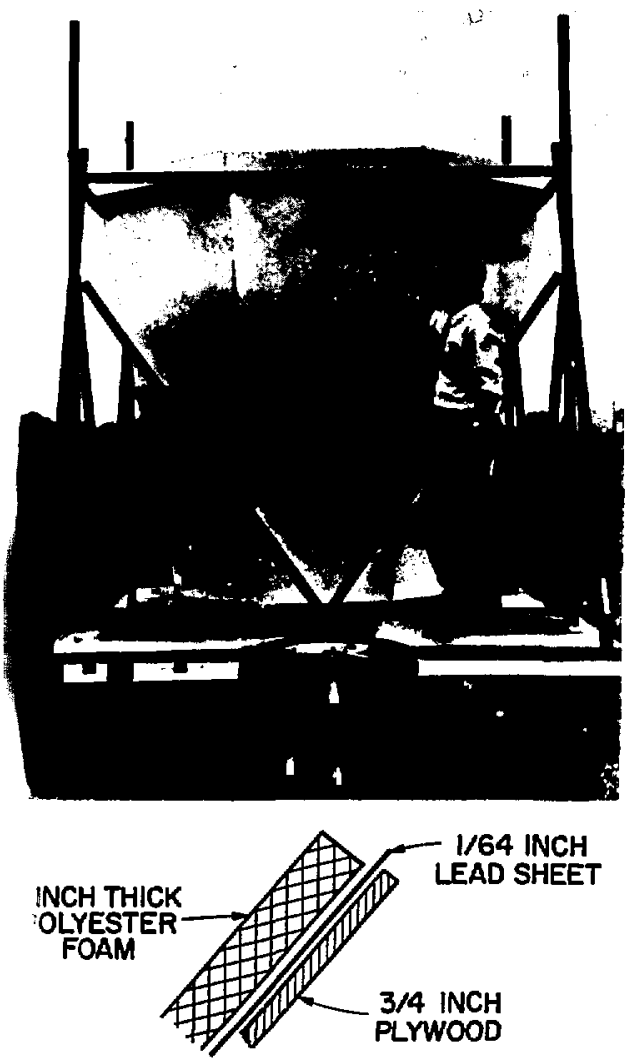

17.--Antenna cuff design. [ANL - No. 301-32-11 Rev. 2] features contributed by the hole in the ground were retained by constructing a 2.4-m-high shield of wood, lead, and special acoustlc foam around the a:tenna. Detalls of the assembly are showm in the photograph and sketch of Figure 17. To prevent ringing between parallel surfaces, the cuff was constructed with walls sloping slightly outward. The simplest design which conserved welyht and space was octagonal in horizontal section, with a 1.5-m inside base diameter (designed to fit the antenna) and a 2 .4-m diameter at the top. Each panel of the sloping-sided, octagonal assembly was a trapezoid measuring $2.4 \times 1.0$ $\times 0.6 \mathrm{~m}(96 \times 39 \times 25 \mathrm{in})$, cut from a single sheet of 3/4-in plywood. A metal frame supported this structure on the flat bed of a standard trailer, directly above the axle. The diameter 
:he cuff at the top was determined by the maximum legal width allowed for lers to be used on the public highway. The holght of the assembly was lally determined by the size of standard plywood panels; but once the asibly was mounted on the traller, the helght was also restricted by the cleaze of standard bridges and highway underpasses. Wooden strips (quarter ad) were used to seal gaps between the plywood panels, and the inslde face of the cuff was lined with acoustic lead sheoting $0.04 \mathrm{~cm}(1 / 64 \mathrm{ln})$ 3k. This dense material provided strong attenuation of sound waves propaing through the cuff walls.

To both absorb internal reflectlons and contribute additional attenuation sounds originating outside the cuff, the lead-lined walls were also covered i $2.54-\mathrm{cm}$-thick ( $1 \mathrm{in}$ ) polyester acoustic foam. This thickness resulted in aximum absorption coefflcient near the usual sounder frequency of $1 \mathrm{kFz}$.

Fine mosquito netting was placed across the top of the cuff in order to sce the intensity of turbulent wind eddies around the transducer. This mesh also effectlve in preventing snow from filling the antenna, and a small hole le bottom of the fiberglass dish permitted ralnwater or melted snow to drain $\gamma$. The complete trailer assembly is rugged, weather-resistant and capable sing towed by a light vehicle at normal hlghway speeds.

Several tests were conducted to evaluate the effectiveness of the moblle in handling the side lobe problems, and the relative effects of the two niques of antenna shielding were compared. These tests ylelded the folng results:

1. Under the same atmospheric conditions and at frequencles near $: \mathrm{Hz}$, the amblent noise levels within the cuff were no more than $5 \mathrm{db}$ er than those observed in the permanent hole; this was still better than , less than the free-fleld nolse intensity.

2. At wind speeds in excess of $7 \mathrm{~m} \mathrm{sec}^{-1}$, the cuff structure acted signiflcant obstruction in the wind field; the resulting wind-Induced nolse slightly greater than the noise generated in the hole by similar winds. ver, in such conditions, simply parking the traller in the lee of a building ced in sounder operating conditions significantly better than those 
sperienced in the permanent hole.

3. Clutter or permanent echoes were effectively eliminated at rural jerating sites, but when soundings using the portable cuff were made in swmtown Chicago, echoes from tall buildings were often detected.

4. The "annoyance factor" caused by the generation of a powerful idio pulse near $1 \mathrm{kHz}$ at regular intervals in a residential area was tested hen the sounder was operated for four days on the campus of the Illinois stitute of Technology (IIT) in Chicago. No complaints were recelved, and ie attention of local residents was attracted more by the unusual appearance $E$ the trailer-mounted cuff than by the strongly attenuated sounds. However, ie very high background levels of amblent noise in the city served to cover le sounder operation, and the same results should not be expected in quiet uburban areas.

5. To evaluate the performance of the cuff in reducing amblent noise vels at the transducer, nolse intensitjes and spectral measurements were made th in and out of the cuff at both city sites and rural locations. All values of und pressure levels were measured with respect to the standard reference of $\times 10^{-4}$ ubar, a pressure level equivalent to a reference intensity of $10^{-12}$ $\mathrm{m}^{-2}$, which at $1 \mathrm{kHz}$ is barely audible to normal human ears. The top record Figure 18 shows measurements of amblent noise made at the IIT site. The oad bandwidth noise intensity (50-20,000 Hz) averaged about 80 to $85 \mathrm{db}$ and jularly reached peaks in excess of $90 \mathrm{db}$ when elevated trains passed within $8 \mathrm{~km}$ of the site (at about one-minute intervals). The cuff provided little ection of this noise, as shown by the second trace in Figure 18.

In similar atmospheric conditions the same type of noise level measurents were made at the essentlally rural site of Argonne National Laboratory; results of these are also displayed in Flgure 18. There appears to have in aí least $15 \mathrm{db}$ difference in the broad bandwidth noise level between clty 1 rural sites; again the cuff seems to offer only minor rejection of nolse. wever, when the character of the nolse levels was investigated by measuring sctra, the signicant advantages of the cuff in rejecting noise at the ingher lio frequencles of principal interest became apparent. Figure 19 represents 
CITY SI IE (CHICAGO CAMPUS) FREE FIELD

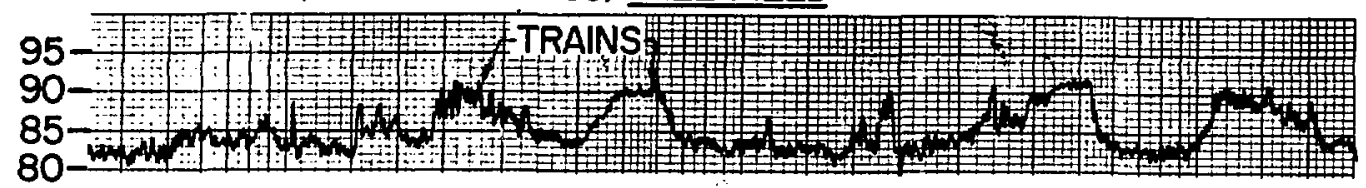

ANTENNA CUFF

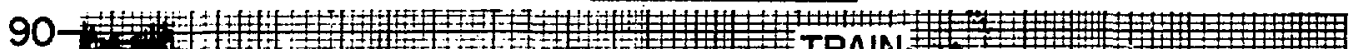
85-

80-

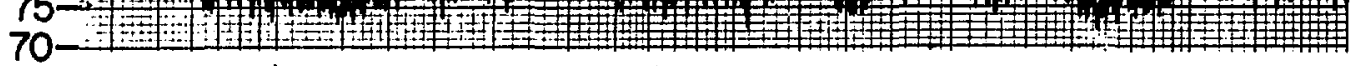
$\vdash 2$ MINUTES $\longrightarrow$
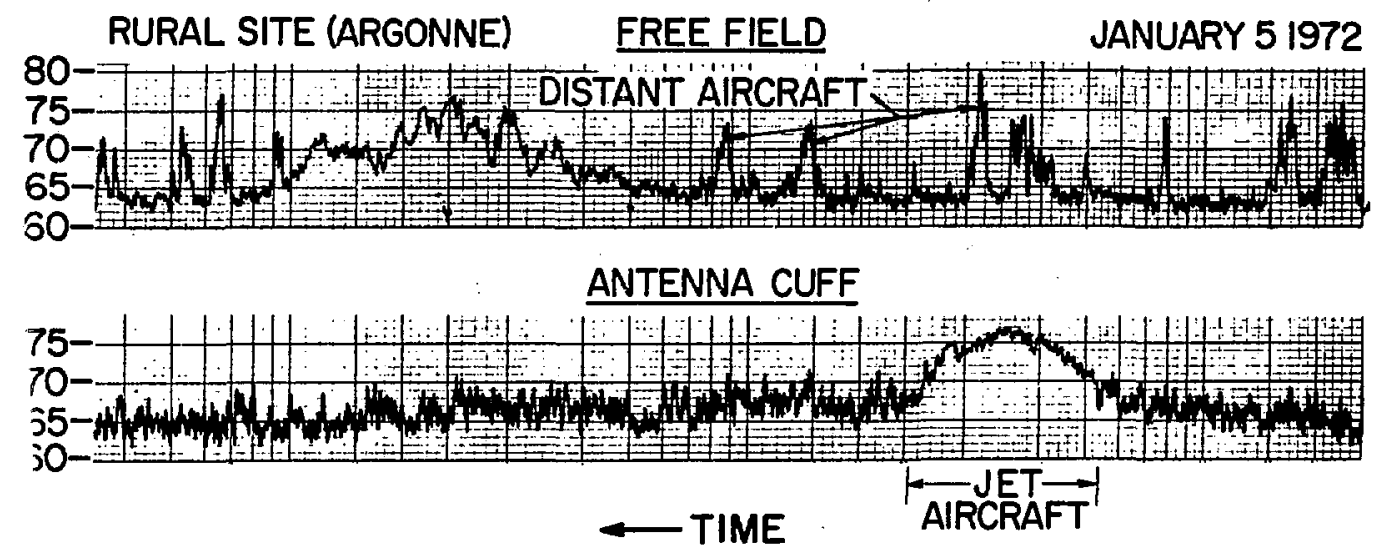

- 18. --Broadband noise levels inside and outside the antenna cuff at urban rural sites. [ANL Neg. No. 149-5477 Rev. 1]

ral acoustic spectra obtained with a General Radio spectrum analyzer using --third-octave filter system. Each of the charts presented in Figure 19 rises at least three spectra measured over a period of $20 \mathrm{~min}$. Since the ning time for each spectrum was about $5 \mathrm{~min}$, it was necessary to assume istant level of ambient noise throughout this period. Since the data in e 18 demonstrate that usually this is not the case, the broad bandwidth : was also monitored during spectral measurements, and the analyzer was srarlly stopped whenever intermittent bursts of noise were detected. 
(db)

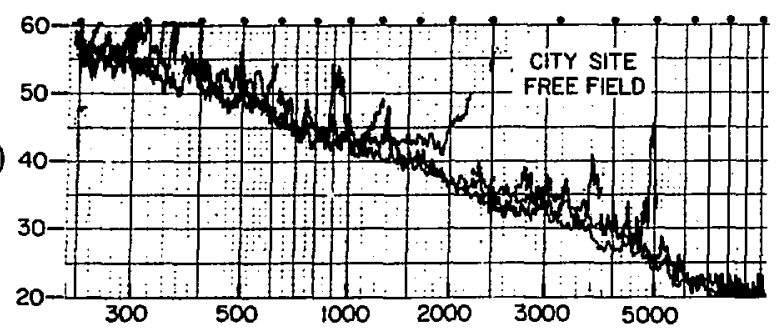

(db.)

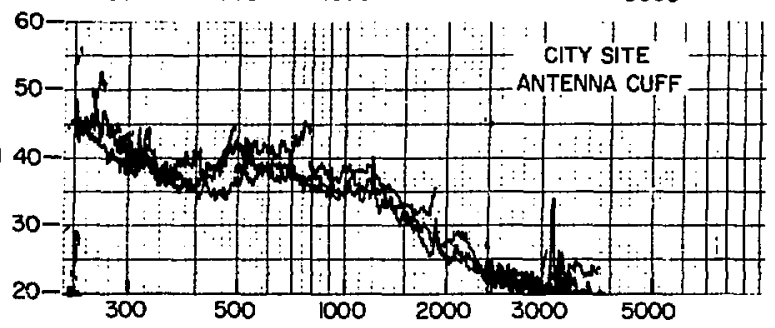

(db)

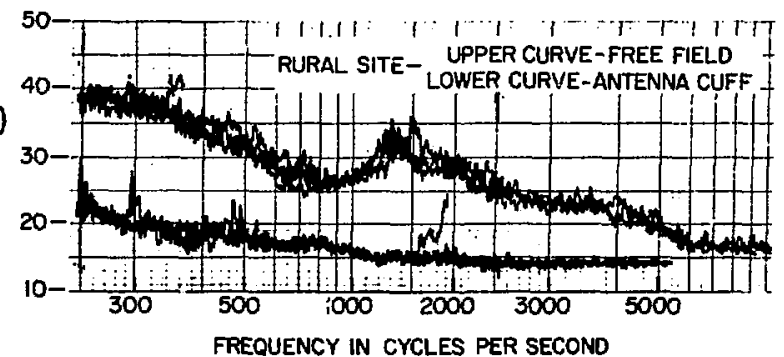

FIG. 19.--Spectral dependence of noise levels as in Figure 18. [ANL Neg. No. 149-5471]

The top charts of Figure 19 obtained at the city site show that at $400 \mathrm{~Hz}$ ise level was about $15 \mathrm{db}$ less inside the cuff than in free space; but the ely flat response curve appearing in the cuff spectra between 400 and $\mathbf{z}$, compared to the uniform decrease over the same interval in the freepectra, means that only about $5 \mathrm{db}$ of noise rejection was offered by the the typlcal acoustic sounder operating frequency of $1300 \mathrm{~Hz}$. However, Iuencies of $2000 \mathrm{~Hz}$ and above the cuff spectra show noise rejections than $10 \mathrm{db}$. Thls suggests that clty experiments using the mobile cuff se Improved by employing a transmitting frequency of at least $2000 \mathrm{~Hz}$. The results of spectral measurements made in similar atmospheric ons in a rural environment are given in the bottom chart of Figure 19. 
Here a maximum in the spectra at $1500 \mathrm{~Hz}$ was obtained in the free-fleld measurements, but not in the cuff. (The source of the noise near $1500 \mathrm{Hiz}$ was probably the motors of force-ventilated sensors operating on a nearby meteorological tower). Thus at the rural site, about $17 \mathrm{db}$ of noise rejection was achleved by the cuff at a frequency of $1500 \mathrm{~Hz}$. About $17 \mathrm{db}$ ciliference at $1500 \mathrm{~Hz}$ was also detected between clty and rural observations in the cuff. This difference in performance accounts for the difference in the quality of acoustic sounder records obtained in urban and rural areas.

In conclusion, the portable traller-mounted cuff has been found to make it feasible to operate an acoustic sounder at a variety of sites, but only limited success was achieved in downtown clty areas. Useful data could probably be obtained in a city environment if a site with lower noise levels were chosen, for example a location on the roof of a tall building or in a quiet park area. In Chicago, a potentially useful site is Meigs Field, a small airport located on the lake front within a mile of the downtown area. Broad bandwidth measurements of nolse at this location recorded on an afternoon with light winds indicated intensities of 65 to $70 \mathrm{db}$ in the free field, values which are comparable with those recorded at some rural sites. In comparison, noise intensities measured at street level in the Chicago clty area varied from about $75 \mathrm{db}$ on a quiet street to peaks of $105 \mathrm{db}$ near the elevated rallroad.

By operating the sounder electronics and the recorder from four 12-volt storage batteries, considerable freedom in site selection was achieved. In this mode, continuous operation for as long as three days is possible. 